\title{
THE SYMBOL OF LIFE BASED ON WILLIAM CARLOS WILLIAMS'S POEM, "SPRING AND ALL" THROUGH STILISTIC VIEW
}

\author{
Jumino \\ English Department, Faculty of Humanities, Diponegoro University \\ juminoya@gmail.com
}

\begin{abstract}
"Spring and All" poem talks about life around us as a simple daily experience, describing the turn of the winter to the coming of the next season, spring. Human life is always changing. Not always happy, symbolized by winter but also not forever suffering, symbolized by spring. Natural suffering is usually a test to achieve happiness. Williams changes his choice of words between two parts of the poem to give the reader a different feeling in the poem that provides a contrast to the ideas of life and death. Through "Spring and All", Williams wants to show the reader how the ideas of life and death can be seen through the transition from winter to spring. He uses dreary imagery (winter) to show sorrow and death, then uses imagery (spring) to live life and hope. Thus, if people think positively, there will be opportunities to improve in the future.
\end{abstract}

Key words: spring, winter, life, death, opportunities

\section{Introduction}

The type of poetry literature is chosen in this study with the primary consideration that the literary work is presented in a concise and meaningful writing. The use of language with the selection of beautiful and meaningful vocabulary makes a poem interesting to explore. Similar to a painting, a poem is also interesting,. The more a poem is read, the more interesting and meaningful it is.

In fact, even ordinary people unconsciously often express poem when they are in a state of joy, depressed, falling in love, and so forth. Likewise the language or poetic expression is often used deliberately in advertisements to attract consumers, such the use of phrases as orange eating oranges, mountainous laundry, feeling like mountain air, making the skin like silk, and so on. It is used primarily to create a dramatic, romantic, elegant, and economical atmosphere.

Poem lovers comprehend a poem and catch its theme the structure and elements presented in the poem. This is similar to the opinion from Pradopo (1987: 3) stating that poetry can be studied on the basis of its structure and elements, such as visual form, sound aspect or musicality, word selection or diction, language style or figurative language, imagery, and other grammatical elements. All elements have important role in building a good poem and they are inseparable in comprehending the meaning of the poem.

In addition to the depth and diversity of meaning, poetry also raises its own beauty values for the audience. Word for word poems are arranged in arrays and stanzas with the arrangement of certain sound rhythms to give special effects to the reader, such as beautiful, romantic, cheerful, happy; or vice versa to bring out a gloomy, dreary, fearful, sad situation and so on. To bring the atmosphere up, poets use the style of language.

The style of language in addition to the aesthetic impact is also an effective tool for comprehending the meaning of a poem. That is why in this article, the author wants to examine the poem "Spring and All" by William Carlos Williams, an American poet, through a stylistic approach. The selection of this poem is based on the author's curiosity regarding the life of Williams conveyed through the poem. 
Furthermore, to examine the poem "Spring and All" by William Carlos Williams above, the writer uses poetic stylist theory which includes elements of diction, imagery, and style of language to get the meaning, ideas, and messages contained in the poem.

\section{Theoretical Framework \\ 2.1. Intrinsic Approach}

This intrinsic approach in William Carlos William's poetry study is focused on diction and imagery. This is intended to support the discussion of the stylistic elements in relation to the language styles contained in the poems.

\subsubsection{Diction}

The poet has the freedom in choosing words that become the media to devote and show his feelings and thoughts. According to Perrine (1969: 38), a primary distinction between the practical use of the language and the literary use is that in literature, especially in poetry: a fuller use is made of individual words. The primary difference between the use of poetic language and the use of the literary language lies in the very high, vocabulary usage subjectivity. This individual's vocabulary arises because the poet wants to gain comfort and satisfaction in expressing his ideas.

Diction contains two elements of denotation and connotation. Denotation is the dictionary meaning of a word. while connotation is the additional meaning that comes from denotation meaning associations. As stated by Perrine (1988: 539), "denotation is the dictionary meaning or meanings of the word." The connotation has more meaning because "it suggests beyond what it expresses: its overtones of meaning." Perrine provides the following examples of denotation and connotation:

The word home, for instance, by denotation means only a place where one lives, but by connotation it suggests security, love, comfort, and family. The words childlike and childish mean characteristic of a child, but childlike suggests meekness, innocence, and wideeyed wonder, while childish suggests pettiness, willfulness, and temper tantrums. (1988: 539)

The word "house" has the meaning of denotation as a place of residence, but it has connotation meaning which includes the sense of security, affection, and the warmth of the family. Then the word "like child" and "childish" refers to the nature of the child. However, the word "like a child" contains more connotations of tenderness, cleanliness, innocence, and the like. The word "childish" contains the connotations of pettiness, selfishness, and irritability,

\subsubsection{Imagery}

Imagery is the delivery of sensory experiences through language, because the images conveyed touch the sense of the reader, so that the reader as if can come to see, hear or feel the images of the conceived by the poet (Perrine, 1969: 54). Humans live to know the environment based on the use of the five senses it has.

The senses are eyes to see, ears to hear, noses to smell, tongue to taste, and skin to feel. This role of the senses is also applied in the creation of a poem. The intent of the poet is to make the poem seem as if life and feel real to the audience, even if it is only through reading. The process of enjoyment of poetry is referred to as image or imagery.

Literary works including poetry cannot be separated from human life, especially the experiences of life that directly experienced or indirectly, These experiences are easily understood through the five senses. The experiences of the spring days, for example, see the blue sky and the white clouds, see the buds of leaves and lilies, hear the robins twittering in the morning, smelling of wet soil and hyacinth flowers, and feeling the fresh air blowing down the cheeks All of that certainly involves the reader's senses while enjoying a poem (Perrine, 1988: 552).

According to Holman (1985: 223), the image is literal and concrete 
representation of a sensory experience or of an object that can be known by one or more of the senses. Imagery is a real representation of the experience by one or more of our senses. Meanwhile, according to Brown \& Olmsted (1962: 179), imagery is an ingredient of all creative writing, because an image is simply a fragment of virtual life which involves the reader's senses (sight, hearing, touch, smell, taste, and so on. Thus, the image or image can be interpreted as a picture of the sensory experience of the reader through the language, whether the sense of sight, hearing, touch, smell, taste, etc. Furthermore Klarer (2004: 180) states that imagery is often regarded as the most common manifestation of the 'concrete' character of poetry. That is, imagery is considered the most common manifestation of the real nature of a poem.

In the imagery, the poet makes every effort to express the experience rather than simply giving information. His effort is to communicate experience, not to convey information. A good and successful image will help the reader feel the poet's experience of the object or situation he is experiencing, giving a precise picture and the image of the mind can be appreciated and feels close to the reader's self-life (Pradopo, 2002: 80).

From the various opinions above, it can be concluded that the image in poetry has an important role because it makes the poem more alive and full of meaning when enjoyed, by stimulating the senses of the connoisseur.

\subsection{Stylistic Approach}

Stylistics is the science of the style of language, how something is expressed in a certain way, so that the intended purpose can be achieved maximally. This relates to the term figurative language. Figurative language is translated from the word trope (Latin), or figure of speech (English), meaning equation or figurative. The types of figurative language are numerous, such as: hyperbole, paradox, sarcasm, inversion, and so on. In general, however, the majors are classified into four groups, namely, affirmation, comparison, contradiction, and sarcasm (Ratna, 2008: 3).

The style of language is the quality of language, which is a direct expression of thoughts and feelings. In the absence of a harmonious relationship between the two symptoms, the style of language becomes absent. In the creative activity of communication between thoughts and feelings are produced continuously from beginning to end of story, so the whole work can be considered to have a style of language.

Furthermore Ratna (2003: 232-233) states that the style of language is the whole way of using the language by the author. Stylistics is a science or theory that deals with speech on language styles. Harsono (1999: 51) focuses that stilistika examines the poetic functions of language, with one of the research steps is to analyze the aspects of figurative language.

\subsubsection{Language Style}

\subsubsection{Definition of Language Style}

There are many definitions of language styles. First, according to Perrine, the style of language (figure of speech) is a way of saying one thing and meaning another. The style of language is a way of expressing against something but with a different purpose, Secondly, according to Keraf (2000: 113), the style of language is a way of expressing the mind through language typically showing the soul and personality of the author (language user). Third, according to Holman (1985: 185), the style of speech (language of speech) as the various uses of language which depart from customary construction, order, or significance in order to achieve special effects or meaning. Fourth, according to Ratna (2008: 164-165), figure of speech is a choice of certain words in line with the intent of the author (poet) or speaker in order to obtain aspects of beauty.

Based on the four opinions above, it can be concluded that the style of language 
is a way of using the language to convey deeper meaning and feel but it feels more beautiful than the language usage straightly. Also the use of language styles can arouse certain effects in the reader's emotions, such as anger, hatred, awe, pity, and so on.

\subsubsection{Types of Language Style}

According to Holman, the style of language (figure of speech) in general is grouped into two types, namely the style of rhetorical language and the style of figurative language or figurative language. The rhetorical figures of speech is a style of speech by using the movement of the use of standard daily language to obtain special effects without changing the basic meaning of the words used. Figures of speech are of two major kinds: rhetorical figures, which are the parts of customary or standard uses of the language. and tropes, in which basic changes in the meaning of words occur(1985: 185).

According Keraf (2000: 129), the style of rhetorical language is solely a deviation from ordinary construction to achieve a certain effect. Some types of rhetorical style include alliteration, assonance, and so on. The figurative language style is the transfer of the uses of meaning, construction, wording to obtain freshness and the power of expression, create the effects of images, describe by analogy, find or gain commonality or vice versa. Examples of these figurative languages are antithesis, apostrophe, climax, hyperbole, irony, metaphor, metonymy, personification, simile, synecdoche, paradox, and others.

According to Perrine (1969: 71), the style of speech has several functions, namely: "First, figurative language affords us imaginative pleasure. Second, figures of speech is a way of bringing more imagery into verse, of making the abstract concrete, of making poetry more sensuous. Third, figures of speech is a way of adding emotional intensity to otherwise merely informative statements. conveying attitudes along with information. Fourth, figure of speech is a means of concentration, a way of saying much in a brief compass."

From the above statement it can be understood that: first, the style of language can create an imaginative pleasure for the connoisseur; second, the style of speech can bring and add images of imagination into poetry so that the image becomes concrete and can be captured by the five senses; third, the style of speech can increase emotional intensity; and fourth, the style of speech is able to reveal many things in a concise and compact form.

\subsection{Metaphor}

The New International Webster's Comprehensive Dictionary of the English Language (2003: 800) states that metaphor is a figure of speech in which one object is likened to another by speaking of it as if it were that: distinguished from simile by not employing any word of comparison, such as' like 'or' as. Meanwhile, Perrine (1987: 565) states that "metaphor is used as a means of comparing things that are essentially unlike. In metaphor the comparison is implied, that is, the figurative term is substituted / or identified with the literal term." Metaphor is used as a means to compare objects that basically have different literal meaning. According to Abrams, metaphor is a way of speaking or writing by comparing one object with another (1971: 78).

Based on the above two statements, it can be concluded that metaphor is a figurative style of language that compares an object with another object directly, without using a comparative word such as, similar to, like, resemble.

\subsection{Simile}

Simile is a style of language that compares two things that basically are not the same as involving comparative words such as, like, similar, and so on. In other words, the comparison in simile is expressed explicitly. Keraf (2000: 138) 
defines a simile or equation as an explicit comparison, i.e., directly declaring things the same as anything else. Birkerts (1993: 583) mentions that simile expresses the fact of likeness with a co. Simile expresses the fact of the similarity between two things by using the word like or like. Abrams, meanwhile, maintains that "a figurative of speech in which one thing is said to be like another thing, or in which two things are over" (1971: 78).

\subsection{Personification}

According to Perrine (1988: 568), personification is the use of human attributes for animals, objects or concepts by giving the attributes of a human being to an animal, an object, or an idea. This language style is a sub type of metaphor which is an implied comparison by using human attributes. Personification is a nonhuman thing or concept is given human attributes (Birkerts, 1993: 599). Similar to Birkerts' opinion, according to Keraf (2000: 140) personification is a figurative style of speech depicting inanimate objects or inanimate items as if they possessed human traits. Reaske reveals personification is the process of assigning human characteristic to non-human objects, abstractions or ideas. Personification is a style of language that gives human properties to things, animals and an idea/concept (Reaske 1966: 39).

\subsection{Symbol}

Generally a symbol can be defined as something that means more than what it means. "The Road Not Taken", for example, concerns the choice made between two paths by people out walking in the woods. It can be interpreted that the choice of road is a symbol for every choice in life between alternatives that appear almost as attractive but will result in a big difference from each path to be traversed. "The Road Not Taken", for instance, concerns a choice made between two roads by a person out walking in the woods (Perrine, 1988: 585).
In addition, Meyer states that the symbol has a deeper meaning than the meaning of the word literally. An object, person, place, event, or action can suggest more than its literal meaning (1995: 581).

\section{Biography of the Poet}

William Carlos Williams was born in Rutherford, New Jersey, on September 17, 1883. His father, William George Williams, of English descent, was born in England and raised in the West Indies. His mother, Raquel Hélène Rose Hoheb Williams, a descendant of French, Spanish and Jewish culture, was born in Puerto Rico.

With his sister, Edward, Williams went to public school in his hometown. When he was fourteen, he traveled with his family to Europe for two years, where he attended the first school in Geneva, Switzerland, and then in Paris.

When his family returned to the United States, he was sent to Horace Mann High School in New York City. He goes every day from Rutherford by tram and ferryboat on the Hudson River. Williams entered the medical school at the University of Pennsylvania in 1902. While there, due to his interest in poetry, he met the poets Ezra Pound and D. H. (Hilda Doolittle) and painter Charles Demuth, who later became lifelong friends.

After graduating from medical school in 1906, Williams was apprenticed in the old French hospital and child care and hospital in New York City. His first poetry collection, Poems, published at his own expense, appeared in 1909. That same year he went to Europe again, where he worked at the pediatrics postgraduate in Leipzig, Germany. While in Europe he renewed his friendship with Ezra Pound, and through him was introduced to writers and pre-war London artists.

After a brief trip to Italy and Spain, Williams returned to Rutherford in 1910 to begin medical practice. In 1911, he married Florence Herman. Over the next few years, Williams became the father of 
two sons, William and Paul. In 1913 he bought a house on 9 Ridge Road in Rutherford which was later left behind for the rest of his life. His second collection of poems, The Emotion, was published in England in the same year.

During the 1940s, Williams contributed his writings to several magazines, including The Glebe, Poetry, Others (then his deputy editor), The Little Review, The Dial, and Broom. He became acquainted with Walter Arensberg, Kenneth Burke, Marsden Hartley, Alfred Kreymborg, Marianne Moore, Charles Sheeler, and poets and painters. Williams published his third collection of poems, $A l$ Que Quiere, in 1917.

Despite his deteriorating health, Williams was still traveling, lecturing, and entertaining writers in the same house that had been visited by members of the Imagist movement more than forty years earlier. He continues to work with the author who is interested in him and his work: Partially crippled stroke In 1958 he suffered a stroke and eventually died on March 4, 1963.

\section{Discussion of the Poem}

\section{Spring and All \\ By William Carlos Williams}

By the road to the contagious hospital under the surge of the blue mottled clouds driven from the northeast-a cold wind. Beyond, the waste of broad, muddy fields

brown with dried weeds, standing and fallen

patches of standing water the scattering of tall trees

All along the road the reddish purplish, forked, upstanding, twiggy 10 stuff of bushes and small trees with dead, brown leaves under them leafless vines-
Lifeless in appearance, sluggish dazed spring approaches-

They enter the new world naked, cold, uncertain of all

save that they enter. All about them

the cold, familiar wind-

Now the grass, tomorrow 2

the stiff curl of wild carrot leaf

One by one objects are defined-

It quickens: clarity, outline of leaf

But now the stark dignity of entrance-Still, the profound change has come upon them: rooted them grip down and begin to awaken

"Spring and All" describes life that is not eternal on earth and we all must recognize that death, as our enemy, which we must face. Death is not a fun thing and cannot be avoided. The events that occur this spring emphasize the counsel and warning of the fact that our lives will end with death.

Spring in general is most often regarded as happy, but Williams does not portray a tone like this. It gives a picture with a darker nature behind life itself. At the beginning of the poem "Spring and All", the tone is depressed, hopeless, moody and somber. This is evident in the use of the phrase "mottled clouds driven from the northeast" (lines 3-4) and "dead, brown leaves under them / leafless vines." (lines 12-13) Both of these phrases imply a depressed tone before the beginning of the poem, allowing us to understand the meaning behind unhappy poetry as one might think.

However, in the last stanza the tone changed to be more hopeful. This is clearly expressed through the phrase "still the profound change / has come upon them and begin to awaken" (lines 25-27). Then this implies a change to the expectation of nature therefore they are called "profound change" (line 25) which allows one to see 
that the despair and gloom of tones has changed. Also by mentioning that someone has started for "awaken" (line 27), The poem takes the tone of hope by adding a resurrection to something better. Thus it can be concluded that according to the poem life is not all good, but otherwise everything is also not all bad.

Lines 14-15 show when people first see the spring. When it appears, the season is described as "sluggish and dazed" (lines 14-15). The poem continues with the mention that spring is "lifeless ... cold ... uncertain" (line 17) and has "stark dignity" (line 24). These words usually apply to humans and show personification.

Line 25, "profound change" which denotes the coming of spring is a metaphor for change that swept across the world in the early 20th century. World War I has ended; people who produce new products and develop art and philosophy, and start enjoying prosperity. Spring has always been a new beginning symbol, and this is Williams's way of expressing his feelings about the turn of the clock. The title of this poem provides insight, counsel, and warning of truth and reality. Speaker in this poem as an omniscient third-person narrator is very concerned to give advice, truth to the reality of human life.

The writing form used in "Spring and All" is partly ranged from free verse. Therefore there is no pattern in the technique of taxation, because it varies including the use of meters. In this way, one can say poetry is always changing like spring life season.

Specific Dictionary using words in "Spring and All" helps even more to indicate the illusion of spring and life. Diction in "Spring and All" is illustrated by the words "the contagious hospital" (line 1). This example of diction creates a somber tone; that there is a gloomy view in the spring. Hospitals are generally considered a place where bad things happen, such as illness and death. This example of diction is important because it is contrasted with the spring itself. It also used harsh words such as "purplish, forked, upstanding, twiggy" (line 10) at the beginning of the poem to adorn the journey and trials that one has faced.

Contradictions appear towards the end of the poem "Spring and All" with soft words such as "clarity" (line 23), "familiar wind" (line 19), and "dazed" (line 15) to describe the happiness of life and the beautiful scenery at the end of the journey life. It is related to the word 'spring' itself. Spring is illustrated as the starting point for life, highlighting the beginnings of life experienced by all human beings.

The poem "Spring and All" consists of long stanza followed by short stanzas and terminated long stanzas, many short lines that proceed to the next line. It symbolizes how the hard life of one's life. This can be interpreted as the end of life and accept its presence. However, after a pause or caesura a more passive change tone. It signifies that life is not eternal on earth and death will arise afterward.

\section{Theme}

The theme analysis over all "Spring and All" by William Williams is spring. This is what Williams used to describe all life itself. It therefore describes life as a journey (as is evident in the first temple "By the road", and the beginning of a definite life through the claim that "They enter the new world naked". This poem is written in free form, meaning not rhyming. It is attributed to the ever-changing human life.

\section{Meaning of Life}

Our speaker is someone who stops by the side of the road, sees the scenery at the end of winter and tells the reader about it. It is about all the information that readers get from this "Spring and All" poem. Through the speaker The reader only knows where and what he is up to, but does not know much else.

This "Spring and All" poem talks about life around us as a simple daily experience, describing the turn of the 
winter to the coming of the next season, spring. Human life is always changing. Not always happy but also not forever suffering, natural suffering is usually a test to achieve happiness.

\section{Conclusion}

Williams changes his choice of words between two parts of the poem to give the reader a different feeling in the poem that provides a contrast to the ideas of life and death.

Through "Spring and All", Williams wants to show the reader how the ideas of life and death can be seen through the transition from winter to spring. He uses dreary imagery to show sorrow and death, then uses carefree imagery to live life and hope. Living in sufferers is still hopeful and it can come true. Of course if people think positive and there are efforts to improve themselves.

\section{Bibliography}

Abrams, M. H. 1962. The Norton Anthology of English Literature. Vol. 2. New York: W.W. Norton \& Company.

1971. A Glossary of Literary Terms. Third Edition. New York: Holt, Rinehart and Winston Inc.

Brown, Wentworth K. dan Sterling P. Olmsted. 1962. Language and Literature. New York: Harcourt Brace \& World, Inc.

Harsono, Siswo. 1999. Metodologi Penelitian Sastra. Semarang: Deaparamartha

Holman, C. Hugh. 1985. A Handbook to Literature. Indianapolis: ITT Bobbs-Merrill Educational Publishing Company Inc.

https://www.enotes.com/Topics/WilliamCarlos-Williams <accessed on Wednesday, 5 August 2017>

https://googleearthpoetics.Wordpress.com/ 2012/04/23/Spring-and-all-
William-Carlos-Williams

<accessed on Thursday, 5 August 2017>

https://www.poetryfoundation.org/poemsand-poets/poets/detail/williamcarlos-williams <accessed on Saturday, 06 May 2017>

https://www.Poets.org/poetsorg/Book/Spri ng-and-All <accessed on Thursday, 03 August 2017>

https://www.Shmoop.com/Spring-andall/speaker.html <accessed on Thursday, 03 August 2017>

Keraf, Gorys. 2000. Diksi dan Goya Bahasa. Jakarta: PT Gramedia Pustaka Utama.

Klarer, Mario. 2004. An Introduction to Literary Studies. New York: Routledge Taylor \& Francis Group.

Perrine, Laurence. 1969. Sound and Sense: An Introduction to Poetry. $3^{\text {rd }}$ ed. New York: Harcourt Brace Jovanovich, Inc.

1988. Literature Structure, Sound and Sense Fifth Edition. USA: Harcourt Brace Jovanovich Publishers.

Pradopo, Rachmat Djoko. 1987. Penghyian Puisi: Analisis Strata Norma dan Analisis Structural dan Semiotik. Yogyakarta: Gadjah Mada University Press.

Ratna, Nyoman Kutha. 2007. Estetika Sastra dan Budaya. Yogyakarta: Pustaka Pelajar.

Reaske, Christopher Russel. 1966. How to Analyze Poetry. New York: Monarch Press. 1970. College Writer's Guide to the Study of Literature. New York: Random House.

Smithm S. Stephenson. 2003. The New International Webster's Comprehensive Dictionary of the 
English Language. Columbia:

Trident Press International. 